\title{
Ekstraordinære kroppe: køn, krop og invaliditet i nyere disability teori
}

Af Bente Meyer

Hvordan paivirker kulturelle forestillinger om abjekte og handikappede kroppe vores opfattelser af kon, og hvorfor har sai mange humanistiske teorier om krop og kon overset den bandikappede krops perspektiv?

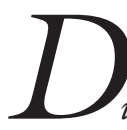

isable: 1. to make (a person) unable to use his/her body properly, 2. to cause (e.g. a machine) to be no longer able to operate, 3.to take away (from a person) a power or right; DISQUALIFX. (Longman Dictionary of English Language and Culture 1992)

"If there is a positive normative task in Gender Trouble, it is to insist upon the extension of ...legitimacy to bodies that have been regarded as false, unreal, and unintelligible" (Judith Butler 1999, xxiii).

I sommeren 2002 opholdt jeg mig af arbejdsmæssige grunde nogle uger på USAs vestkyst, hvor jeg var et interesseret vidne til forskellige indlæg på tre konferencerl, som fokuserede på køn, krop og andethed. Emnerne var disability, queerness og kønsteori, ofte med henblik på dialogerne mellem disse. Hvordan kan feltet disability studies, som fokuserer på den invaliderede og abjekte krop, bidrage til køns- og ikke 
mindst queer teorierne, og hvordan opstår der nye felter af interesse for kønsforskningen af disse teoretiske perspektiver og kropslige erfaringer, var nogle af de væsentlige spørgsmål, som konferencerne stillede.

I det følgende vil jeg forsøge at give nogle svar på spørgsmålene, samt at introducere til nogle af de teoretiske perspektiver, som ligger bag felterne disability studies, feminist disability studies og queer disability studies. Af min fremlægning vil det fremgå, at disability er et ustabilt begreb, der, som queer, kun vanskeligt lader sig oversætte til dansk ${ }^{2}$. Som queer peger disability således på mærkeliggørelser af de herskende forestillinger om kroppen, forestillinger som er regulative, normative og tvangsprægede. Der er tale om, hvordan bestemte sandhedsbærende forestillinger om sunde, hele og potente kroppe mødes i og stigmatiserer bestemte kroppe, men også om, hvordan kønnet og seksualiteten er indlejret i den abjekte krops diskurs. I denne forstand er disability studies tæe knyttet til queer teoriernes radikale kropsanalyser. Som queer teoretikeren Robert McRuer siger det, genererer disability forskningen "ability trouble" (McRuer 2002), fordi den spørger til stabiliteten og autoriteten af den sunde, raske og kompetente krop, der generelt fremstilles som normalen. Disability studies konfronterer os med den måde, hvorpå kroppe tildeles betydning, men også med den diversitet og foranderlighed som karakteriserer kroppens forskellige manifestationer.

\section{DisABILITY - ET KOMPLEKST BEGREB}

Disability teorien er, som queer teorien, udsprunget af politiske bevægelser i 60erne og 70erne, der relaterer til, hvordan normative kropsopfattelser påvirker og især undertrykker enkeltindividers og gruppers frie udfoldelse. I disability teoriens tilfælde er udgangspunktet 60'ernes handikapaktivisme, dvs. politiske angreb på dels biologiske og lægefaglige definitioner af handikappede som syge og ugyldige individer, dels sociale og kulturelle undertrykkelsesmekanismer, der har forhindret handikappede i at deltage i samfundsaktiviteter på lige fod med andre individer. På den ene side er den vestlige kulturs historie rig på eksempler på, hvordan biologiske konstruktioner af handikappede kroppe har ført til medicinering, indespærring, regulering og 'kurering' af angiveligt abnormale kroppe, ud fra en forestilling om, at uforståelige og 'defekte' kroppe måtte integreres i og tilpasses den til enhver tid gældende normalitetsforestilling. På den anden side har forskellige arkitektoniske og ideologiske konstruktioner forhindret handikappede $\mathrm{i}$ at agere som frie og selvberoende individer i demokratiske samfund. Samfundet er altså, er parolen, i sig selv 'handikappende', og bygger på en determinerende og abjektgørende forestilling om "ableism".3 Som forfatteren og handikapaktivisten Eli Clare opsummerer det: "The disability rights movement, like other social change movements, names systems of oppression as the problem, not individual bodies. In short, it is ableism that needs the cure, not our bodies" (Clare 1999, 106, min kursivering).

I 80'erne og 90'erne er disability studies på lykkelig vis blevet koblet til poststrukturalistiske og konstruktivistiske teorier, som fokuserer på handikap og invaliditet som kulturelle og sociale, i modsætning til 'biologiske' konstruktioner, og som ikke mindst kobler analyserne af den anderledes krop til Foucault-inspirerede magtanalyser. Foucaults historiske tolkning af normen som en specifikt moderne konstellation kan anskueliggøre, hvordan stigmatisering genereres ud fra undertrykkende forestillinger funderet i fysisk fremtræden og kropslighed, som Rosemarie Garland Thomson påpeger det i sit disability teoretiske manifest Extraordinary Bodies. Figuring Physical Disability in American Culture and Literature (Thomson 1997a, 39). Disability begrebet og -feltet peger dermed ikke længere 'kun' på 'materielt' handikappede krop- 
pe og handikappedes rettigheder, men i lige så høj grad på kulturelle og sociale magtrelationer, der stigmatiserer og invaliderer bestemte kroppe. Begrebet er dermed, som queer begrebet, blevet komplekst og ustabilt, eftersom definitionen af, hvem der er handikappet nu, afhænger af, i hvor høj grad den eller de, der skaber kategorierne, har internaliseret magtens diskurser. "It bears remembering”, påpeger således Karen Elizabeth Jung, "that there is no precise or universally accepted definition of disability: defining disability is a practice of power wherein the category can be contracted or expanded in accordance with the vested interests of the definer" (Jung 2002, 178, min kursivering). Fra at handle om diagnose, behandling og rehabilitering af handikappede kroppe i omsorgssociale og lægefaglige kontekster, er disability begrebet altså vandret ind i forskellige humanistiske forskningskontekster, hvor det har solidariseret sig med de kritiske kropsanalyser, som i disse år præger bl.a. felterne cultural studies, queer og gender studies.

\section{HUMANIORAS BLINDHED}

Disability studies er et interessant felt for humanistisk forskning, og ikke mindst for kønsforskningen, fordi det kan bruges til at rekonstituere og analysere abjekte og diskvalificerede kropsformer, men også fordi det kan anvendes til at pege på blinde punkter i humanioras egen forskningstradition. I en tid, hvor den humanistiske forskning har været stærkt optaget af kroppens repræsentationer i især vestlige kulturkredse, er den handikappede eller invalide krop blevet overset af forskningen, der hovedsageligt har valgt at fokusere på kroppen, som det sted hvorfra jouissance, seksualitet og overskridende erfaringer udspringer, men ikke som en kategori, der nogen gange er "differently abled".

Forsømmelsen, hævder disability teoretikeren Lennart J. Davis, skyldes tilsyneladende en ideologisk forestilling om ableism, der inden for akademia fortrænger og udgrænser dysfunktionelle kroppes virkelighed. Dette skal ikke mindst ses i sammenhæng med de Foucault og queer inspirerede kropsanalyser, der nok har lagt vægt på alternative kropsidentiteter såsom homoseksualitet, hermafrodisme, galskab m.m., men som stadig er funderet $\mathrm{i}$ den fungerende krops lyst og performative styrke. "So much of left criticism has devoted itself to the issue of the body, of the social construction of sexuality and gender. Alternative bodies people this discourse...But lurking behind these images of transgression and deviance is a much more transgressive and deviant figure: the disabled body" (Davis 1995, 5). Ableism, den raske og potente krops ideologi, har forblændet de humanistiske kropstolkninger og -teorier, der følgelig ikke har haft blik for, at kroppen også er foranderlig og ustabil i selve sin konstruktion som kød og materialitet.

Løsningen på denne forsømmelighed er naturligvis at angribe teoriernes handikapfobi, at gøre sig det klart, hvordan disability teorien kan oplyse og transformere de discipliner, der hævder at tage udgangspunkt i, hvordan kroppe repræsenteres og tolkes i vestlige kulturkredse. Vi kan begynde med queer teorien: ifølge Butler er kønnet og seksualiteten tvunget ind i heteronormative konstruktioner af kroppen, der naturaliseres via gentagne handlinger, der er blevet internaliseret. Butler hævder, at disse handlinger har en 'hallucinatorisk' indvirkning på vores opfattelse af kønnets og identitetens matricer, eftersom vi forveksler, det vi gor med, det vi er, dvs. "What we take to be an internal essence of gender is manufactured through a sustained set of acts, posited through the gendered stylization of the body... at an extreme, an hallucinatory effect of naturalized gestures" (Butler 1999, XV). Queer teoriens sigte må i forlængelse af dette, groft sagt, blive at denaturalisere den magt og stabilitet, som kønnet har i disse kulturer. Queer teorien er en urovækkende teori, der rammer 
kønskategoriernes realitet og autoritet. Men denne autoritet sættes der tilsyneladende ikke grundlæggende spørgsmålstegn ved, når det handler om subjektets kropslige stabilitet og handlekraft, jf. ableism. I en nyligt udgivet artikel i tidsskriftet NWSA Journal leverer Ellen Samuels således en kritik af Butlers værk ud fra en disability teoretisk vinkel. Butlers værk, hævder hun, åbner tilsyneladende umiddelbart masser af muligheder for at kritisere den diskvalificering og marginalisering, som invaliderede individer, herunder handikappede, rammes af i normative samfund. For eksempel spørger Butler i Excitable Speech: A Politics of the Performative: "How does that materialization of the norm in bodily formation produce a domain of abjected bodies, a field of deformation, which in failing to qualify as the fully human, fortifies those regulatory norms?" (Butler 1997, 15, citeret i Samuels 2002). Spørgsmålet, der for mange handikappede associerer til eksempelvis problematiske diskussioner om liv, der er værd at leve, lægger op til at diskutere den handikappede krops problematik, men denne problematik nævnes aldrig af Butler i bogen, eller i de øvrige værker hun har skrevet. Butler udfordrer altså aldrig grundlæggende den kropsnorm, som konstituerer kroppen som kompetent, hel og sund, og som er central for disability teorien. Den handikappede krops erfaringer og representationer synes at være Butlers blinde punkt. Som Ellen Samuels formulerer det, "Butlers most compelling conclusions about how bodies are sexed can inform our analysis of how bodies are "abled"; however, her work itself is enabled by its own reliance upon a stable, functional body that is able to walk, talk, give birth, see and be seen" (Samuels 2002, 65, min kursivering). Hvis queer teorien altså har haft sine væsentlige sejre i relation til at vise, hvordan kønnet tvinges ind i naturaliserede forestillinger, baseret på den heteroseksuelle normativitet, så har den i mindre grad interesseret sig for den marginalisering og norma- tive tvang, som generelt rammer kroppe, der ikke kan identificeres som kompetente, handlekraftige og potente. Som det vil vise sig, er dette en markant og afgørende fortrængning, eftersom de kulturelle forestillinger om abjekte og invalide kroppe ofte netop er forbundet med kønslige konstruktioner, der definerer kvindelige, transseksuelle og homoseksuelle kroppe som monstrøse, sygelige og vanskabte. Kønnet og seksualiteten er integreret i det abjektes diskurs.

\section{DISABILITY STUDIES - ET FEMINISTISK FELT}

Hvis kroppen, sådan som disability teorien hævder det, er et ustabilt og radikalt udgangspunkt for den tolkning, som forankrer identiteten i kroppen, så må kønsforskningen interessere sig for, hvordan kønnet konstrueres i kroppen, og hvordan det interagerer med abjekte kropskategorier, som for eksempel race, homoseksualitet og ikke mindst invaliditet. I en række tekster, udkommet fra midt i 90'erne, om forholdet mellem disability studies og kønsteori diskuterer Rosemarie Garland Thomson således, hvordan feminisme, kønsteori og disability teori kan berige hinanden ved at stille spørgsmål til og udfordre de normative og marginaliserende magtdiskurser, som kønnet så ofte har været underlagt (Thomson 1996, 1997a\&b, 2002a\&b). De feministiske teoriers og kønsteoriernes aktuelle undersøgelser af kroppens rolle i identitets- og magtrelationerne kan blive et udgangspunkt for at gøre feminisme og kønsforskning til mere inkluderende felter, hævder således Thomson, ikke mindst hvis de beriges med disability teoriens politiske og teoretiske perspektiver. Som Thomson formulerer det:

"Both feminism and my analysis of disability challenge existing social relations; both resist interpretations of certain bodily configura- tions and functionings as deviant; both question the ways that differences are invested with 
meaning; both examine the enforcement of universalising norms; both interrogate the politics of appearance; both explore the politics of naming; both forge positive identities" (Thomson 1997a, 22)

Thomsons feminisme er altså på den ene side et åbent, "universaliserende" perspektiv (Sedgwick 1990)4, der stiller radikale spørgsmål til undertrykkelsens strategier, og på den anden side en feminisme, der beskæftiger sig med, hvordan kvindeligt kønnede kroppe påvirkes af diskurser om defekte, mangelfulde og abnorme kroppe. I vestlige kulturer har således ikke mindst kvinder været udsat for medicinering, indespærring og tilfældig diagnosticering ud fra en forestilling om, at kvindekønnet er det monstrøse, bysteriske køn. Den kvindelige krop har med støtte i centrale vestlige teorier - herunder eksempelvis psykoanalysen været repræsenteret som sygelig, deform og mangelfuld, en stigmatisering, som den kulturelle og samfundsmæssige sexisme kun har forstærket. Ikke mindst skønhedsindustriens forestillinger om, at den kvindelige krop til alle tider har haft behov for korrektion og forbedring $\mathrm{i}$ form af f.eks. kirurgi, kosmetik og forskellige former for indsnøring og opstramning har gennemgående præget kulturelle forestillinger om 'naturlig' kvindelighed i sexistiske samfund. Som Rosemarie Garland Thomson påpeger det, er eksempelvis de seneste 15-20 års støt stigende annoncemateriale for kosmetisk kirurgi ofte præget af påstanden om, at kropslige indgreb og modificeringer producerer 'naturligt udseende' næser, bryster, lår og hager, en diskurs, hævder Thomson, der understøtter forestillingen om kvinders umodificerede kroppe som unaturlige og unormale, og ikke mindst kirurgisk forandrede kroppe som normale og naturlige (Thomson 1997b, 287). Dertil kommer, at almene, kulturelle idealer om kvindelig skønhed som værende forbundet med slanke kroppe og europæiske træk, genererer kropslige hierarkier, hvori den smukke, hvi-

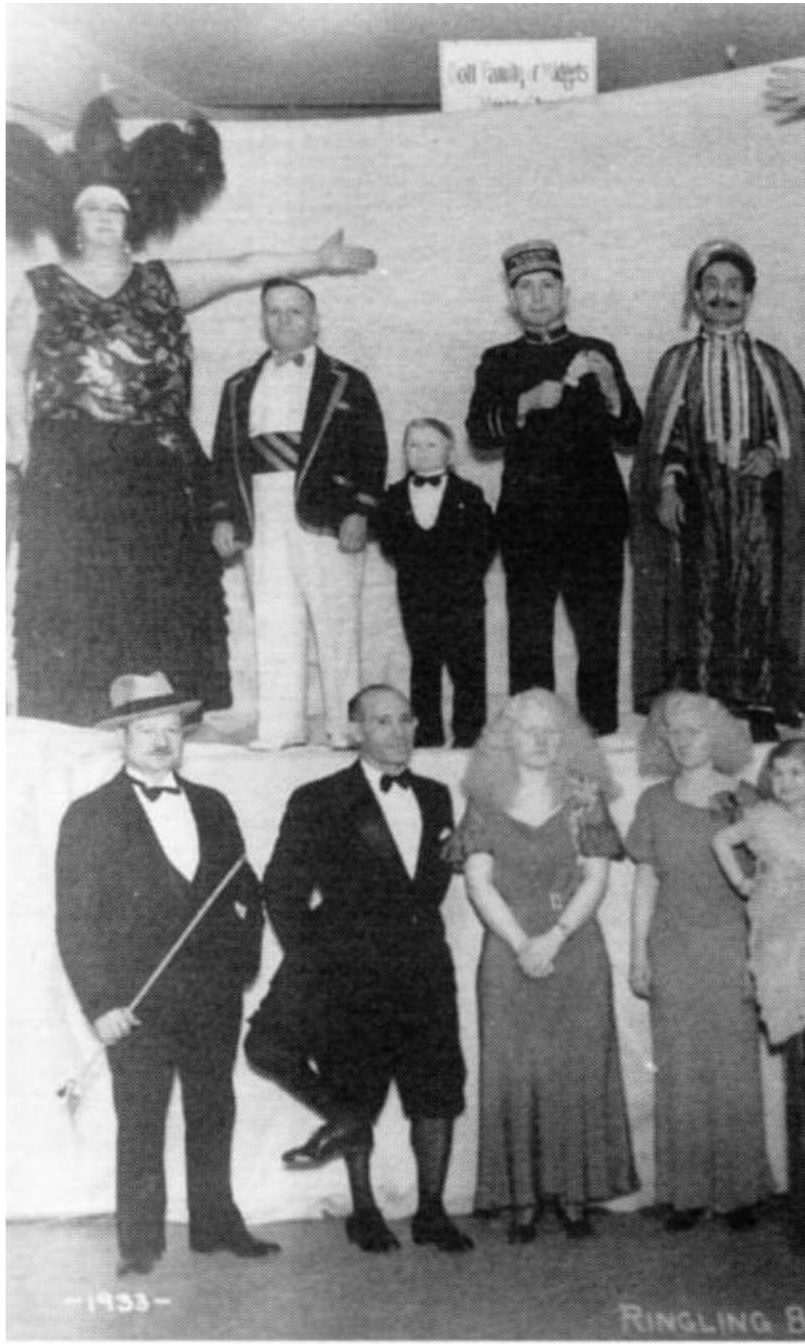

de, heteroseksuelle og slanke kvinde fremstår det anatomiske ideal, på baggrund af hvilket eksempelvis farvede, fede og lesbiske kvinder i varierende grad fremstår som 'grimme' eller 'abnorme'. April Herndon, der skriver om kulturelle forestillinger om og angst for fedme og 'unaturlige' kropsstørrelser (fatphobia og weightism) påpeger eksempelvis, at kvinder med store kroppe er dobbelt marginaliserede pga. kulturelle og sociale konstruktioner af kvindelighed og 


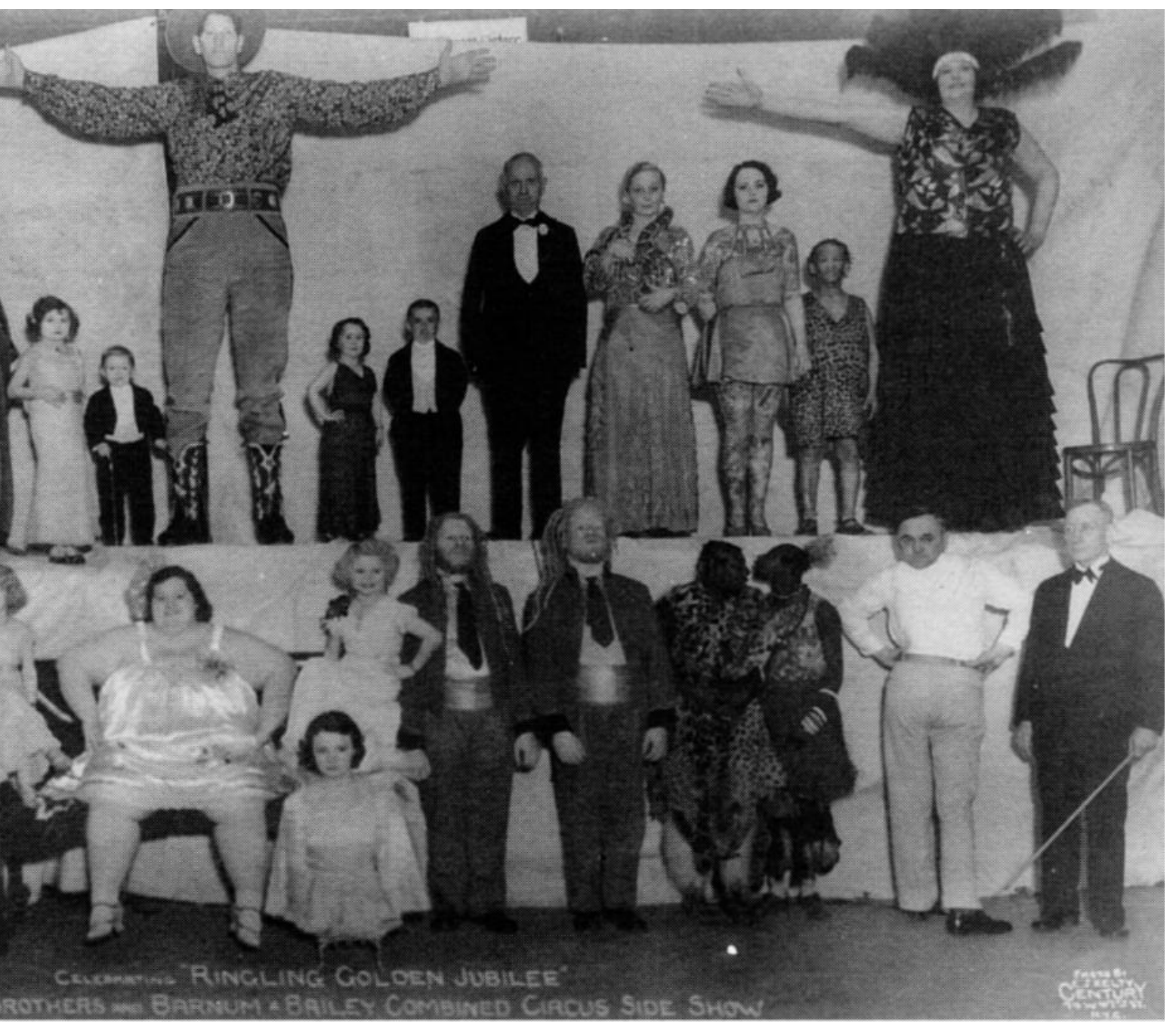

Edward J. Kelty: Celebrating Ringling GoldenJubilee. Ringling Brothers and Barnum \& Bailey Combined Circus Side Show (1933).

fedme som stigmatiserede kropsligheder. Som hun ser det, er feminist disability studies netop det teoretiske perspektiv, som kan udfordre sådanne kulturelt funderede fordomme, eftersom: "Fatness and disability... remind us that bodies are subjected to changing socio-cultural contexts as well as physiological changes" og "recognizing this fluidity moves away from ideas of inherently flawed individuals and towards accounts of dynamically situated bodies and identities" (Herndon 2002, 132). Selve jegets ustabile og foranderlige konstitution, som den anskueliggøres af kroppens metamorfoser i forbindelse med f.eks. sygdom, alderdom, invaliditet, fødsler, vægttab eller fedme er en central dagsorden for feminist disability studies, eftersom kvindelige kroppe oftest stigmatiseres af normative forestillinger om uforanderlighed, konformitet og potens.

Følgen af alt dette bliver, som Iris Ma- 
rion Young fremhæver det, at kvinder i sexistiske samfund er 'fysisk handikappede', eftersom kulturelle og samfundsmæssige forventninger til, hvordan kvinder bør (op)føre sig, forhindrer dem i at agere frit i deres kroppe. Kvinder, konkluderer Thomson på bl.a. Youngs udtalelser, er blevet fremstillet som den vestlige kulturs urfre$a k s$, og kvindelighed synes dermed i sig selv at være en form for genetisk betinget handikap, der uafladeligt definerer kvinder som abnorme, som det andet køn. Dette skal ikke mindst ses på baggrund af et kulturgrundlag, der favoriserer heteroseksualitet, sundhed, hvidhed, skønhed og maskulinitet, uhelligt forenet $\mathrm{i}$ det som Thomson kalder "the normate" (Thomson 1997a). De nye feministiske teorier, af Thomson kaldet feminist disability studies, kan altså udfordre den regulative normativitet, som forudsætter en universel, kropslig ide om mandlighed, herunder andre privilegerede kropskategorier.

En sådan disability teoretisk transformation af feminismens genstandsfelt må, hævder Thomson som nævnt, forudsætte en mere inkluderende feminisme, i det omfang at feminismen traditionelt fokuserer på de erfaringer og teoretiske genstandsfelter, der omfatter hovedsageligt kvindeligt kønnede individer. De feministiske teoriers forestilling om kvinden har således nok siden de postmoderne diskursers gennemslag gjort en del ud af at insistere på den heterogenitet, som gemmer sig under betegnelsen kvinde, men har alligevel kun sjældent taget højde for handikapspecifikke og unikke, abjekte, kropslige erfaringer forbundet med kvindeligt kønnede kroppe. Denne kritik af feminismen sekunderes ikke mindst af et nyligt udkommet nummer af tidsskriftet Hypatia om "Feminism and Disability", der hævder at, "Among women the practice of treating the well-functioning female body as the primary locus of womanhood sometimes leaves disabled women seeing themselves as less than women" (Kittay et al 2001, viii) og "feminism needs to turn to disability theory in order to deconstruct the normalization that oppresses disabled women as disabled women" (Schriempf 2001, 54). Feminismen, hævder både Thomson, Kittay, Schriempf og andre, har været indlejret $\mathrm{i}$ den kulturelle diskurs om ableism.

\section{MONSTRØSE KROPPE}

Men hvis især kvindekønnet og dets erfaringer med abjekte diskurser om kroppen er centrale for feminist disability studies, så må kønnet dog aldrig forstås som den eneste kategori, der er væsentlig i analysen af, hvordan kroppen konstrueres som abjekt. Thomson uddyber således sin pointe om disability perspektivets nødvendighed for det kønsteoretiske projekt i en række kulturanalyser, der illustrerer, at kønnet som kropskategori altid spiller sammen med faktorer som race, seksualitet, klasse og kropslig integritet. Selv om kvindeligt kønnede kroppe ofte har været forbundet med det patologiske og abnormale, har kulturelle forestillinger og fortællinger om kvindelighed også på interessant vis interageret med kulturelle forestillinger om race og seksualitet, som bl.a. har været med til at generere vanskabningen som kulturel kategori. Thomsons analyser af kønnets repræsentationer i en handikapfobisk kultur fokuserer således ofte på de 'monstrøse' kropsligheder, som især i det 19. århundrede har været udstillet til forargelse for og underholdning af de brede, normative masser. Der er tale om f.eks. de victorianske freakshows, dvs. om en skuekultur, i hvilken blikket konstituerer og konstruerer abnormaliteten som kategori. Denne abnormalitet anskueliggøres og repræsenteres i freak showets iscenesættelse af det afvigende, af specifikke, markerede kroppe, som f.eks. skxggede damer, 'hottentotter', 'abemennesker', dværge og kæmper. Disse 'vanskabninger', hævder Thomson, bærer som oftest kønnets, deformitetens og etnicitetens tegn, "Freaks always appeared not just as 
monsters, but as gendered and racialized monsters" (Thomson 1997a, 29).

Med blikket som fokus for den kritiske kulturanalyse kan disability teorien altså dekonstruere de magtrelationer, som genererer monstret og vanskabningen ud fra eksisterende historiske forestillinger om kvindelighed, etnicitet og kropslig dysfunktion som patologiske og unaturlige kropsidentiteter. Den 'unaturlige' krop kommer i dette stigmatiserende blik til at fremstå som en særlig ondartet krænkelse af normaliteten, som på en gang fascinerer og frastøder den, der kigger på. Monstret og den vanskabte krop repræsenterer derfor for betragteren det ikke-jeg, som normaliteten søger at udskille og andetgøre, den monstrøse krop er selve den præmis, hvoraf konstruktionen af det normale afhænger.

Men denne præmis kan også fremskrives: Hvis de victorianske freakshows i et vist omfang fremstår som anakronistiske spektakler og dermed synes at henvise blikkets kulturanalyse til en svunden tid, så har dette blik, som bl.a. Eli Claire fremhæver det, bestemt ikke mistet sin magt i en voyeuristisk, homofobisk og handikapfobisk kultur, nemlig vores egen. Clare, der benævner sig selv som crip queer (krøbling og queer) ${ }^{5}$, trækker således en lige linie fra udstillingerne af de vanskabte freaks til den daglige nedstirring, der rammer hende selv (og andre som hende) som repræsentant for mindst to diskvalificerede kropsidentiteter. Hun taler om: "the transition from freak show to doctor's office, from curiosity to pity, from entertainment to pathology. The end of the freak show didn't mean the end of our display or the end of voyeurism. We simply traded one kind of freakdom for another" (Clare 1999, 87, min kursivering). Set fra Clares synspunkt er det normative blik stadig determinerende for den marginalisering og diskvalificering, som visse kroppe udsættes for, dvs. det normaliserende blik konstruerer den stigmatisering, som udskiller bestemte kroppe af mængden af kroppe og definerer dem som andet, som abnormale, vanartede. Om dette blik siger Thomson tilsvarende med reference til feminismens diskussioner af blikkets objektiverende magt:

"Whereas feminists claim that women are objects of the male gaze which demarcates their subjectivity...the disabled body is the object not of the appropriating gaze but of the stare. If the male gaze informs the normative female self as a sexual spectacle, then the stare sculpts the disabled subject as a grotesque spectacle...the stare is the material gesture that creates disability as an oppressive social relationship" (Thomson 1997b, 285)

Blikkets kultur- og kønsanalyse har altså i og med disability teorien bevæget sig væk fra et relativt snævert mand-kvinde perspektiv henimod et bredere social- og kulturanalytisk perspektiv, hvor blikkets funktion som stigmatiserende og abjektgørende kraft påvirker den måde, hvorpå vi forstår og kategoriserer anderledes kroppe. En sådan analyse må have betydning for ikke kun den måde, hvorpå anderledes kroppe fascinerer og frastøder vores synssanser, men også for de visuelle kulturer, som vi omgiver os med i form af f.eks. film, billeder og artefakter. Disability studies er derfor et felt, som på eksemplarisk vis kan associeres med kulturog medieanalyser, dvs. med kritiske tolkninger af de repræsentationer af handikappede eller abjekte kroppe, som medie- og populærkulturerne genererer. Thomson har således selv foretaget en række analyser af den ekstraordinære krops betydning og fremtoning i forskellige medier, f.eks. fotografiet, reklamen og litteraturen, og om disse siger hun i Enabling the Humanities:

"Understanding how images create or dispel disability as s system of exclusions and prejudices is a move toward the process of dismantling the institutional, attitudional, legislative, economic, and architectural barriers that keep people with disabilities from full participation in society" (Thomson 2002b, 75) 
Opsummerende kan man altså med Clare og Thomson hævde, at der med disability studies og feminist disability studies muliggøres en gentænkning af kønnet som krop, ikke kun i relation til den diskussion af begreberne sex og gender, som queer teorien har bragt på banen, men som en bredere repræsentations-, identitets- og erfaringskategori, der indbefatter disability perspektivet, ikke mindst via dikotomien ableism/disability. Feminist disability studies bør i denne forbindelse ikke kun snævert knyttes til kønnet kropslige repræsentationer, men netop bredes ud til at omfatte de mangeartede og mangfoldige identitetskonstruktioner, som residerer i kroppen. "Disability perspectives reveal the broad array of cultural norms which privilege an illusory ideal of mind and body at the expense of our actual bodies of all shapes and sizes", som Abby Wilkerson påpeger det, (Wilkerson 2002: 36), disability studies og feminist disability studies søger at udfordre de sociale og kulturelle strukturer, som vil homogenisere kropslige udtryk og identiter i normalitetens navn.

Som kønsteori er Thomsons feminist disability teori i forlængelse af dette både, på den ene side, feministisk, idet den undersøger og solidariserer sig med kvindelige erfaringsformer, især de der relaterer til handikapfeltet. På den anden side, er den i Sedgwicks forstand "universaliserende", dvs. forbundet med en bredere og mere radikal kritik af identitets- og kønspolitikken. Thomsons feminisme er $\mathrm{i}$ denne forstand også tæt knyttet til queer perspektivet, dvs. til queer teoriens ambition om at legitimere det aparte, at indtage selve det apartes og abjektes position. Som Butler selv siger det i Gender Trouble: "If there is a positive normative task in Gender Trouble, it is to insist upon the extension of...legitimacy to bodies that have been regarded as false, unreal and unintelligible" (Butler 1999, xxiii). Feminist disability studies kan i forlængelse af dette opfattes som en radikal, konstruktivistisk udfordring til køns- og identitetspolitikken.

\section{QUeER Disability STUDies6}

Hvor Thomsons disability teoretiske fokus i f.eks. Extraordinary Bodies hovedsageligt ligger på de dialoger, intersektioner og teoretiske overlapninger, som eksisterer mellem feminisme, kønsforskning og disability teori, så kan hendes tolkninger af abjekte kropskategorier som eksempelvis kvindelighed bruges til at restituere adskillige marginaliserede og diskvalificerede kropskategorier, som har været betragtet som unaturlige, uvirkelige og uforståelige, jf. Butler. En af disse kategorier er queerness, der som Eli Clare fremhæver det, er en kropskategori, der altid er blevet patologiseret og medikaliseret af centrale kulturelle magtinstitutioner, dvs. at "queer people have been told for centuries by church, state and science that our bodies are abnormal" (Clare 1999, 96). Queer disability er dermed dobbeltbundet $\mathrm{i}$ de to regulative magtkonstruktioner, som queer teoretikeren Robert McRuer, med inspiration fra Adrienne Rich, har kaldt henholdsvis compulsory heterosexuality og compulsory able-bodiedness (Rich 1986, McRuer 2002). " Like compulsory heterosexuality...compulsory ablebodiedness functions by covering over, with the appearance of choice, a system in which there actually is no choice" hævder således McRuer med henvisning til bl.a. Butler (McRuer 2002, 92).

Queer disabled er i forlængelse af dette en stærkt marginaliseret kropsidentitet, der både fremstår som paradoksal (forklaring følger) og som i høj grad overskridende i relation til heteronormative og handikapfobiske samfundskonstruktioner. Eftersom både handikappede og homoseksuelle kroppe ofte er blevet forbundet med enten overdrevne eller underdrevne fysiske karakteristika, eksempelvis 'for meget' eller 'for lidt' seksualitet, dværgvækst, overdreven vækst m.m., er identiteten queer disabled et både flertydigt og paradoksalt udgangspunkt for forståelsen af den komplekse, kropsbundne identitetskonstruktion. Hvis homoseksualitet eksempelvis er konstrueret 
som en hyperseksualiseret kropskategori og 'handikappet' som en afseksualiseret kropskategori, hvordan er det da overhovedet muligt at være både handikappet og queer?7 På den anden side vil netop andre kropsidentiteter end de heteroseksuelle, raske og potenserede overhovedet være i stand til konstruere alternative seksualitetsforståelser, der eksempelvis udfordrer de normative kulturers fiksering på genitale seksualitetsformer. Susan Wendell, der som Thomson arbejder for at integrere disability perspektiver med feministiske perspektiver, hævder f.eks. at individer, der lever og forstår sig selv som disabled, har særlige forudsætninger for at udfordre de kulturelle myter om kønnets og seksualitetens beskaffenhed, som vi omgiver os med i vestlige kulturer. Wendell hævder eksempelvis, at nogle (handikappede) individer kan få orgasmer i alle de dele af kroppen, som er følsomme for berøring. "Few able-bodied people know these things" påpeger Wendell, "and to my knowledge, no one has explored their implications for the able-bodied" (Wendell 1997, 274). Hvis man, som også Butler fremhæver det, altså skal spørge til, hvordan begær og seksualitet determineres af kulturelle forestillinger om kroppens erogene zoner (Butler 1999, 89), skal man måske inddrage de erfaringer, som individer der definerer sig som disabled eller queer disabled, bidrager med.

Seksualitetsspørgsmålet er således kun et af de mange interessante spørgsmål, som opstår af den kritiske tænkning, der kombinerer queer og disability perspektiverne.

Queer disability studies var netop emnet for en konference, den første af sin slags, der blev afholdt på University of San Francisco i juni 2002. Et af hovedspørgsmålene på konferencen var, hvordan begreberne "crip" og “queer" kunne redefineres ud fra de homoseksuelles, transseksuelles og 'handikappedes' egne erfaringer og visioner, men også hvordan disse redefinitioner af det marginaliserede identitetsfelt queer crip kunne etableres som et teoretisk felt, der inkluderede queer og disability teori, samt narrative, kunstneriske og aktivistiske repræsentationer af de kroppe, som måtte kategoriseres inden for dette felt. Spørgsmålet om, hvem der har adgang til repræsentationerne af og fortællingerne om kroppen, blev fremhævet af bl.a. de mange personlige fortællinger, der reflekterede over kropslig andethed og herskende kropsforståelser. Pointen var ikke mindst, at den ekstraordinære krop må fortælles, hvis den skal forstås i sin kompleksitet, dvs. hvis den skal fungere som en moddiskurs til normativitetens kanoniserede fortællinger. Anderledes kroppe kan yde modstand mod tvangens politik, men kun hvis de bringes 'ud af skabet' og i konfrontation med normative representationskategorier, der anskueliggør kroppens rolle i konstruktionen af det som Thomson har kaldt "the normate".

At fortælle kroppen kan dermed blive en understregning af, hvordan kropslig forskellighed kan blive en moddiskurs til samfundets forsøg på at disciplinere og kurere 'uforståelige' kroppe. Som både queer og 'krøblinge' havde mange af de tilstedeværende på konferencen erfaret på deres egne kroppe, hvad det vil sige ikke at passe ind i de herskende, binære kønssystemer eller i idealet om ableism. Mange var blevet udsat for fysiske overgreb i form af f.eks. kirurgi og 'revalidering', andre var blevet nægtet retten til at definere deres egne kroppe eller tvunget til at undertrykke eller fortrænge deres 'tilbøjeligheder'. Den samfundsmæssige og kulturelle trang til at kurere, regulere og disciplinere ekstraordinære kroppe vidner om den magt, som normative forestillinger om køn, seksualitet og kropslig sundhed og integritet har i mange vestlige samfund, og ikke mindst om, at disse forestillinger konstrueres i relation til specifikke, abjekte kropsligheder, der er bundet til bl.a. køn og seksualitet. Det er disse konstruktioner af det normale via forestillingerne om det abjekte, som disability teorien kan hjælpe os med at få øje på. 


\section{DISABILITY TEORI: ET OVERSÆTTELSESPROBLEM?}

At redefinere kroppe, køn og identiteter via disability teorien må involvere ikke mindst den humanistiske kønsforskning i nye terminologikampe, der kan anskueliggøre hvilke teoretiske og forskningsmæssige perspektiver, der måtte befinde sig i begrebet disability, sammenlignet med f.eks. de gængse, men i denne forbindelse utilstrækkelige, begreber handikap og invaliditet. I Danmark (og i Norden som sådan) har vi til sammenligning valgt ikke at oversætte begrebet queer, der i sin 'mærkelighed' og ubestemmelighed synes uoversætteligt til vores i øvrigt ordknappe sprog. Disability er i denne forstand - og mange andre - beslægtet med queer, ikke mindst fordi disability teorierne, som queer, både er "minoritiserende", dvs. forbundet med bestemte minoritetsgruppers erfaringer og politiske krav, og "universaliserende", dvs. forbundet med mere radikale angreb på normative matricer. Der er ingen stabil definition af disability termen, som Karen Elizabeth Jung fremhæver det ovenfor, eftersom stabiliteten $\mathrm{i}$ de sandhedsbærende identitetskonstruktioner netop er, hvad disability teorierne angriber og denaturaliserer.

Til gengæld kan man håbe på, at oversættelsesproblematikken ikke kommer i vejen for en nordisk tolkning af disability teorierne.

\section{NOTER}

1. Disse var The first International Conference on Queerness and Disability på San Francisco State University, The Disability, Difference and Tolerance Conference i Oakland, Californien og The 23rd National Women's Studies Association Conference i Las Vegas. Jeg henviser desuden til min artikel om konferencerne I NORA, Nordic Journal of Women's Studies 2002, 3.

2. Jeg har, i denne artikel valgt, at bibeholde det engelske ord. Jeg har også, i min tekst, været nødt til at bruge danske synonymer, i de tilfælde, hvor man på engelsk ville bruge glosen disability. Disse synonymer er f.eks. den abjekte, deforme, handi- kappede, invaliderede, dysfunktionelle krop osv. Hvis denne begrebsglidning giver uklarheder, skyldes dette altså hovedsageligt oversættelsesproblemer.

3. "Ableism" kan nærmest oversættes som den sunde og raske krops ideologi.

4. I modsætning til et "minoritiserende" ("minoritizing") perspektiv, som hævder, at bestemte diskurser, eksempelvis queer teori og disability studies, udelukkende henviser til bestemte minoritetsgrupper (homoseksuelle og handikappede), vil et "universaliserende" ("universalizing") perspektiv hævde, at de undertrykkelsesmekanismer, som normativiteten skaber, er af betydning for alle, der måtte overtræde normativitetens forbud.

5. Som queer er crip et forsøg på at generobre en nedsættende eller negativ term og bruge den som et politisk våben. Corrie Sandal fra Florida State University talte i forlængelse af dette på Disability, Difference and Tolerance konferencen i Oakland om begrebet "cripping" som "the act of exposing stereotypes, drawing attention to exclusionary norms", "revealing what is under the surfarce" og "performing subtexts through parody".

6. Robert McRuer og Abby Wilkerson udgiver i slutningen af 2002 et særnummer af GLQ A Journal of Lesbian and Gay Studies om Queer Disability Studies. Særnummeret bærer titlen "Desiring Disability: Queer Theory Meets Disability Studies” (vol 19 nol-2) Duke University Press. Nummeret var desværre ikke på gaden, da denne artikel blev skrevet.

7. Spørgsmålet blev stillet af Ellen Samuels i avisen The Bay Area Reporter vol 32 no 23, 6 juni 2002

\section{LITTERATUR}

- Butler, Judith (1999): Gender Trouble. Feminism and the Subversion of Identity. Routledge, New York and London.

- Butler, Judith (1997): Excitable Speech: A Politics of the Performative. Routledge, New York.

- Clare, Eli (1999): Exile and Pride. Disability, Queerness and Liberation. South End Press, Cambridge MA.

- Davis, Lennart J. (1995): Enforcing Normalcy: Disability, Deafness and the Body. Verso, New York. - Herndon, April (2002): "Disparate But Disabled: Fat Embodiment and Disability Studies" in "Feminist Disability Studies” ed. Kim Q. Hall, special issue of NWSA Journal, vol.14, No 3, Indiana University Press

· Jung, Karen Elizabeth (2002): “Chronic Illness 
and Educational Equity: The Politics of Visibility", in, "Feminist Disability Studies" ed. Kim Q. Hall, special issue of NWSA Journal, vol.14, No 3, Indiana University Press.

- Kittay, Eva et al. (eds.): (2001) Hypatia. A Journal of Feminist Philosophy. "Feminism and Disability" Part 1 vol.16, number 4. Indiana University Press.

. McRuer, Robert (2002): "Compulsory Ablebodiedness and Queer/Disabled Existence" in Rosemarie Garland Thomson, Brenda Jo Breuggeman, and Sharon Snyder (eds.) Enabling the Humanities: A Disability Studies Sourcebook, New York: MLA Press.

- Meyer, Bente (2002): "Extraordinary Stories: Disability, Queerness and Feminism" in NORA, Nordic Journal of Women's Studies no 3, vol. 10 Taylor \& Francis

- Rich, Adrienne (1986): "Compulsory Heterosexuality and Lesbian Existence", in Blood, Bread and Poetry, Norton, New York.

. Samuels, Ellen (2002): "Critical Divides: Judith Butler's Body Theory and the Question of Disability", in, "Feminist Disability Studies" ed. Kim Q.Hall Indiana, special issue of NWSA Journal vol.14, No3, University Press

- Schriempf, Alexa (2001): "Refusing the Amputated Body: An interactionist Bridge for Feminism and Disability" in Hypatia. A Journal of Feminist Philosphy "Feminism and Disability" Part 1, vol.16, no 4 Indiana University Press

- Sedgwick, Eve Kosofsky (1990): The Epistemology of the Closet. University of California Press, Berkeley.

. Thomson, Rosemarie Garland (2002a): "Integrating Disability, Transforming Feminist Theory" in "Feminist Disability Studies" ed. Kim Q.Hall, special issue of NWSA Journal, vol.14, No 3 Indiana University Press.

. Thomson, Rosemarie Garland (2002b): "The Politics of Staring: Visual Rhetorics of Disability in Popular Photography" in Disability Studies. Enabling the Humanities, The Modern Language Association of America

- Thomson, Rosemarie Garland (1997a): Extraordinary Bodies. Figuring Physical Disability in American Culture and Literature. Columbia University Press, New York.

. Thomson, Rosemarie Garland (1997b) "Feminist Theory, the Body, and the Disabled Figure" in The Disability Studies Reader ed. Lennart J. Davis, Routledge
. Thomson, Rosemarie Garland (ed.) (1996): Freakery. Cultural Spectacles of the Extraordinary Body. New York University Press, New York. . Wendell, Susan (1997): " Toward a Feminist Theory of Disability" in The Disability Studies Reader ed. Lennart J. Davis, Routledge

-Wendell, Susan: (1996) The Rejected Body: Feminist Philosophical reflections on Disability. Routledge, New York.

-Wilkerson, Abby (2002): "Disability, Sex Radicalism, and Political Agency" in: "Feminist Disability Studies" ed. Kim Q. Hall, special issue of NWSA Journal, vol.14, No 3, Indiana University Press - Young, Iris Marion (1990): Throwing Like a Girl and Other Essays in Feminist Philosophy and Social Theory. Indiana University Press, Bloomington.

\section{SUMMARY}

This article aims to introduce the reader to the fields of disability studies, feminist disability studies and queer disability studies, and to discuss how these theoretical positions can open up new enquires in Nordic queer and gender studies. The article sets out by exploring how specifically the American tradition of disability studies can challenge body perspectives brought up by different gender theories in the humanities. The argument is, that although Nordic gender studies in the past decade or two have been very much focused on issues of the body and bodily representation these academic perspectives have not been aware of the often radical questions of embodiment generated by academic disability theories. Consequently, if body issues in queer, women's and gender studies in the Nordic countries are enriched with disability perspectives and disability theory, these studies will be transformed, specifically with regard to intersectional body issues. Finally the article discusses how the term "disability" can be translated into the Nordic languages.

Bente Meyer, lektor

Institut for Pxdagogisk Antropologi, DPU

Redaktør af NORA, Nordic journal of Women's Studies 